\title{
Late Ediacaran post-collisional magmatism in the Guéra Massif, South-Central Chad
}

\section{GREG SHELLNUTT, MENG-WAN YEH, NGOC HA T. PHAM AND TUNG-YI LEE}

National Taiwan Normal University

Presenting Author: jgshelln@ntnu.edu.tw

The Guéra Massif of South-Central Chad is primarily composed of Late Ediacaran basement rocks that record the collision and post-collisional evolution of the Central African Orogenic Belt. Collisional granites were emplaced at 595-590 Ma but there are post-collisional intrusions that were emplaced over the next 25-30 million years. Post-collisional granitic rocks were emplaced at two distinct intervals. The older granites have zircon $\mathrm{U}-\mathrm{Pb}$ weighted-mean ages of $569 \pm 6 \mathrm{Ma}, 568 \pm 7 \mathrm{Ma}$, and $568 \pm 6 \mathrm{Ma}$, whereas the younger granites have ages of 556 $\pm 7 \mathrm{Ma}$ and $561 \pm 6 \mathrm{Ma}$. Both groups of post-collisional granites are peraluminous, ferroan, and alkali calcic to calc-alkalic but intermediate microgranular enclaves were observed within the older granites. The chemical variability of each group can be explained by fractional crystallization but it is likely their parental magmas were derived by partial melting of the lower crust. The Nd isotopes of the older rocks $\left(\varepsilon_{\mathrm{Nd}}(t)=-9.5\right.$ to -1.2$)$ are slightly less enriched than the younger rocks $\left(\varepsilon_{\mathrm{Nd}}(t)=-13.1\right.$ and -9.1). Moreover, the $\mathrm{Nd}$ isotopic compositions appear to indicate the presence of isotopically juvenile basement rocks around the Mongo (west) region and ancient basement rocks in El Hidjer to Zan (east) region. The older group was emplaced during a period of crustal thinning after oblique collision and shearing related to the final suturing of the Congo-Saõ Francisco Craton and the Saharan Metacraton. The younger group was emplaced after a period of regional WNW-ESE directed crustal shortening. The punctuated nature of deformation/crustal relaxation cycles suggest that there may have been many small terranes rather than larger cratonic blocks involved in the lithotectonic evolution of the Central African Orogenic Belt north of the Congo-Saõ Francisco Craton. 